\begin{tabular}{|c|c|c|c|c|c|c|c|c|c|c|}
\hline Sample Number: & $\begin{array}{l}\text { TABLE I- } \\
\text { O No. } 1\end{array}$ & $\begin{array}{l}\text {-RESULTS } \\
\text { ONO. } 2\end{array}$ & $\begin{array}{c}\text { ON SAMPLES C } \\
\mathrm{H}\end{array}$ & $\begin{array}{c}\text { of KNOW COMPOSITtON: } \\
\text { I }\end{array}$ & $\begin{array}{l}\text { ANILINE } \\
J\end{array}$ & $\begin{array}{l}\text { METHOD FC } \\
\text { U No. } 1\end{array}$ & $\begin{array}{l}\text { OR FILIER } \\
\text { U No. } 3\end{array}$ & G No. 1 & $c$ & $G$ No. 14 \\
\hline COMPOSITION OF SAMPLES & (Percentag & & & & & & & & & \\
\hline Pure Rubber (Fine)..... & 40.3 & 40.3 & 40,3 & 40.0 & 30.0 & 40.0 & 40.6 & 37.0 & 24.44 & $37.0(a)$ \\
\hline 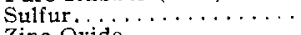 & 2.0 & 2.0 & $\begin{array}{r}2.0 \\
18.9\end{array}$ & 4.0 & $\begin{array}{r}3.0 \\
30\end{array}$ & 3.0 & 3.0 & 3.0 & $\cdots$ & 3.0 \\
\hline $\begin{array}{l}\text { Zinc Oxide } \\
\text { White Lead (Dutch) } \ldots . . .\end{array}$ & $\begin{array}{l}18.9 \\
18.9\end{array}$ & $\begin{array}{l}18.9 \\
18.9\end{array}$ & $\begin{array}{l}18.9 \\
18.9\end{array}$ & $\cdots$ & 30.0 & 14.0 & 56.4 & 30.0 & iij & 30.0 \\
\hline $\begin{array}{l}\text { White Lead (Dutch ....... } \\
\text { I }\end{array}$ & $\begin{array}{r}18.9 \\
9.9\end{array}$ & $\begin{array}{r}88.9 \\
9.9\end{array}$ & $\begin{array}{r}10.9 \\
9.9\end{array}$ & $\cdots$ & $\cdots$ & $\cdots$ & $\cdots$ & $\ldots$ & 4.44 & $\ldots$ \\
\hline Hydrated Iime........... & 2.0 & 2.0 & 2.0 & $\ldots$ & $\ldots$ & $\therefore$ & $\ldots$ & & 6.67 & $\cdots$ \\
\hline Litharge $\ldots \ldots \ldots \ldots \ldots$ & 8.0 & 8.0 & 8.0 & & $\cdots$ & 10.0 & $\cdots$ & 15.0 & 6.67 & $\cdots$ \\
\hline Whiting................ & $\cdots$ & $\cdots$ & $\cdots$ & 26.0 & $\cdots$ & $\cdots$ & $\cdots$ & $\cdots$ & $\cdots$ & $\cdots$ \\
\hline Iithopone.............. & $\cdots$ & $\cdots$ & $\cdots$ & 20.0 & & $\cdots$ & $\cdots$ & $\cdots$ & $\cdots$ & $\cdots$ \\
\hline Vermilion $\ldots \ldots \ldots \ldots \ldots$ & $\cdots$ & $\cdots$ & $\cdots$ & . & 15.0 & $\cdots$ & $\cdots$ & ‥ & $\cdots$ & 100 \\
\hline$\ldots \ldots \ldots \ldots$ & $\cdots$ & $\cdots$ & $\cdots$ & $10^{\circ}$ & ... & $\cdots$ & $\cdots$ & $\cdots$ & $\ddot{6} \dot{6}$ & 10.0 \\
\hline Golden Antimony ....... & $\cdots$ & $\cdots$ & $\cdots$ & 10.0 & & $\cdots$ & $\cdots$ & $\cdots$ & $26.6 i$ & $\cdots$ \\
\hline Magnesium Oxide....... & $\cdots$ & $\cdots$ & $\cdots$ & $\cdots$ & 5.0 & $\cdots$ & $\cdots$ & $\cdots$ & $\cdots$ & $\cdots$ \\
\hline Aluminum Flake....... & $\cdots$ & $\cdots$ & $\cdots$ & $\cdots$ & $\begin{aligned} 17.0 \\
\ldots\end{aligned}$ & 3.30 & $\cdots$ & $\cdots$ & $\cdots$ & $20 \dot{0}$ \\
\hline 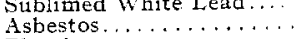 & $\cdots$ & $\cdots$ & $\ldots$ & $\ldots$ & $\cdots$ & $\cdots$ & $\ldots$ & $\cdots$ & 11.11 & $\ldots$ \\
\hline 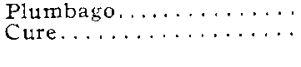 & $20 \times 40$ & $90^{\circ} \ddot{\times} 40$ & $\begin{array}{l}100 \times 250^{\circ} \\
\text { ANAI, YTICAL }\end{array}$ & $\begin{array}{l}\text { F. } 100 \times 250^{\circ} \mathrm{F}, 100 \\
\text { L RESLLTS (PERCENTAGES) }\end{array}$ & $\begin{array}{l}\times 250^{\circ} \mathrm{F} . \\
\text { BY ANILINE }\end{array}$ & $\begin{array}{l}80^{\circ} \times 30 \\
\text { E MFTHOD }\end{array}$ & $130 \times 38$ & $\cdots$ & $60^{\prime} \times 60 \mathrm{lbs}$ & $s \ldots$ \\
\hline Fillers Found $\ldots \ldots \ldots \ldots$ & $\left\{\begin{array}{l}58.76 \\
58.71\end{array}\right.$ & $\begin{array}{l}59.36 \\
59.43\end{array}$ & $\begin{array}{l}58.72 \\
58.40\end{array}$ & $\begin{array}{l}55.00 \\
54.70\end{array}$ & $\begin{array}{l}67.03 \\
67.79\end{array}$ & 58.60 & $\begin{array}{l}57.56 \\
57.40\end{array}$ & 60.03 & 74.11 & 60.44 \\
\hline Organic Acetone Extract & 1.09 & 1.23 & 1.03 & 1.31 & 0.74 & 0.99 & 1.19 & 1.29 & 0.80 & 5.04 \\
\hline Free Sulfur............ & 0.42 & 0.20 & 0.97 & 4.50 & 2.24 & 0.88 & 2.00 & 1.82 & 0.30 & 1.48 \\
\hline Rubber..... & 39.75 & 39.17 & 39.44 & 39.34 & 29.60 & 39.53 & 39.33 & 36.86 & 24.79 & 33.04 \\
\hline Fillers in Dish $\ldots \ldots \ldots$ & $\{0.10$ & 0.18 & 0.47 & 0.00 & $8.2 \mathrm{I}$ & 0.32 & 9.32 & 0.44 & 1.43 & 3.60 \\
\hline & 10.00 & 0.36 & 0.82 & 0.09 & 5.51 & . & 6.95 & $\cdots$ & $\cdots$ & $\cdots$ \\
\hline
\end{tabular}

is very slow to dissolve, while this does not occur if the material is properly vulcanized.

We found that in a few cases an additional digestion with half the quantity of solvent for 5 hours reduced the amount of mineral fillers about 0.5 per cent. In specification work it is advisable to make this second digestion after the ether has been expelled from the tube by heating.

In Table I, Samples O No. I and O No. 2 are the same, except that $\mathrm{O}$ No. 2 was purposely overcured. Sample $H$ was prepared using the same recipe as for Samples O Nos. I and 2, but by another manufacturer. Samples H, I and J were unintentionally undercured. Sample $C$ is a hard valve. Sample G No. I4 contains Caucho rubber.

Analysis of the fillers showed that the rubber as found by difference did not include all the sulfur of vulcanization.

It will be noted that the sum of the percentages of rubber found and of the organic acetone extract is slightly greater than the percentage of rubber used in the recipe.

The fllers during vulcanization and afterwards in the course of analysis have combined with sulfur to form new compounds. If this combination of fillers and sulfur is a substitution of sulfur for some other acid radical, the resultant product would usually weigh less than the sum of the ingredients entering the reaction and the rubber found by difference would be slightly greater thereby.

We expect to continue these experiments when other samples are available, and a final report will be made on the subject when we shall have all the data at hand.

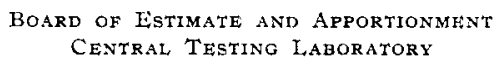

\section{THE FREE CARBON OF WOOD-TAR PITCHES}

By H. K. Benson and L. L. Davis

Received November 27,1916

In the examination of wood tars, it was found that the so-called "free-carbon" of the residuums was exceptionally high as determined by the methods generally employed for this purpose. ${ }^{1}$ It was accordingly

t Office of Public Roads, U. S. Dept. Agric., Bull, 314, p. 25. considered worth while to ascertain whether the carbonaceous residue from carbon disulfide extraction really consisted of carbon or of probable hydrocarbons that are insoluble in carbon disulfide. Previous work had already shown a marked variation in the solubility of bitumens in the usual petroleum solvents, wood-tar pitch being almost completely insoluble in petroleum distillates or turpentine, and only slightly soluble in benzol.

The relative solubility of bitumens was therefore determined in carbon disulfide and acetone by the usual method. The resulting residue insoluble in a given solvent was in each case again extracted with the other solvent. The wood tars were obtained from the experimental wood distillation plant at the University of Washington, from a commercial plant in Oregon and from a hard wood distillation plant in Michigan. Commercial coal-tar pitches were taken from a local Barrett plant, the petroleum asphalt from a city paving plant and the Trinidad asphalt from a laboratory sample. The results are given in Table I.

\begin{tabular}{|c|c|c|c|c|c|c|}
\hline \multirow[b]{2}{*}{ SAMPLE } & \multicolumn{2}{|c|}{$\begin{array}{c}\text { INSOLUBLE IN CS } \\
\text { Residue } \\
\text { a }\end{array}$} & \multicolumn{2}{|c|}{ INSOLUBLE IN } & \multirow{2}{*}{$\begin{array}{c}\text { MELT- } \\
\text { ING } \\
\text { POINT } \\
{ }^{\prime} \mathrm{F} \text {. }\end{array}$} & \multirow[b]{2}{*}{$\begin{array}{l}\text { AsH } \\
\text { Per } \\
\text { cent }\end{array}$} \\
\hline & $\underset{\text { cent }}{\text { Per }}$ & $\begin{array}{c}\text { insoluble } \\
\text { in } \\
\text { acetone }\end{array}$ & $\begin{array}{l}\text { Per } \\
\text { cent }\end{array}$ & $\begin{array}{c}\text { Residue } \\
\text { insoluble } \\
\text { in } \mathrm{CS}_{2}\end{array}$ & & \\
\hline Douglas fir pitch. & 67.7 & $59.7 \%$ & 57.7 & $57.8 \%$ & 200 & 2.9 \\
\hline las & 62.5 & 30. & 31 & & 18 & 1.0 \\
\hline ouglas fir pitch. & 93.1 & 35.3 & 34.6 & 34.4 & 150 & 0.8 \\
\hline ouglas fir pitel & 60.2 & 22 . & 21 & 21 & 1.30 & 0.1 \\
\hline ard wood pitch. & 18.7 & 3 & 2.9 & & 90 & 0.1 \\
\hline Hard wood pitch. & 59.9 & 18. & 17.5 & 17.4 & 180 & 0.9 \\
\hline oal-tar pitch. & 27.4 & 27 & 57.5 & 27.1 & 209 & 1.7 \\
\hline oal-tar pi & 22 & 22 & 37.1 & 22.3 & 16 & 0.6 \\
\hline oal-tar pi & 18.4 & 18 & 35.3 & 18.5 & 140 & 0.1 \\
\hline oal-tar pitc & 17.4 & 17 & 33 & 16.9 & 116 & 0.0 \\
\hline 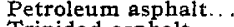 & 4 & 4 & & 3 & $?$ & 0.0 \\
\hline & & & 69. & 41.8 & 150 & 31.2 \\
\hline
\end{tabular}

CONCLUSIONS

I-The free carbon of wood-tar pitches cannot be determined by carbon disulfide.

II-Acetone is suggested as a solvent in this determination for wood-tar pitches.

III-Coal-tar pitches may be classed with the native and the manufactured asphalts for the determination of free carbon.

LABORATORY OF INDUSTRIAL, CheMistry UNIVERSITY OF WASHINGTON SeatTle 